\title{
Right of Workers are Guaranteed in the Constitution
}

\author{
Siti Marwiyah ${ }^{1}$, M. Syahrul Borman ${ }^{2}$, Bachrul Amiq ${ }^{3}$, Vieta Imelda Cornelis ${ }^{4}$ \\ \{siti.marwiyahsh@unitomo.ac.id $\left.{ }^{1}\right\}$ \\ ${ }^{1,2,3,4}$ Dr. Soetomo University, Indonesia
}

\begin{abstract}
The constitution has provided protection for workers/laborers to get paid for their work as a form of protection of human rights for every citizen. However, in the implementation of the Manpower Act and the Bankruptcy Law = Act found differences in norms regarding the rights prioritized payment. According to the Manpower Act, if the company is declared bankrupt, the payment is prioritized to the worker/hunter, while in the Bankruptcy Law the payment is to the separatist creditor.
\end{abstract}

Keywords: Payment of Wages for workers/laborers

\section{Introduction}

The world of employment in Indonesia is faced with very complex problems. Various criticisms were aimed at the Indonesian government, which in general was still considered not serious or even failed to deal with labor problems [1], [2]. One problem is the problem of protecting workers' rights. Employment rights are often the topic presented in various labor actions that take place every May 1 (commemorating International Labour Day) in connection with the non-implementation of these rights by the state (government) or company. Companies that ideally provide protection actually issue policies that harm or not humanize them [3].

Related to the world of labor Constitution in article $28 \mathrm{D}$;

Paragraph (1): "Everyone has the right to recognition, guarantee, protection, and legal certainty fairness and equal treatment before the law ",

Paragraph (2): "Every person has the right to work and receive compensation and treatment fair and decent work relations".

And implementively from the constitution there are 2 (two) rules that govern regarding employment, namely Law No. 13 of 2003 concerning Labour (UUK), Article 95 paragraph 4 states that in the event that a company is declared bankrupt or liquidated based on applicable laws and regulations, then the wages and other rights of the workers/laborers are debt the payment takes precedence. But vice versa Law No. 37 of 2004 concerning Bankruptcy and Postponement of Obligations of Debt Payments (PKPU Law).

\section{Problem}

For 2 (two) regulations concerning worker rights/in terms of priority payment of wages there is a disharmony between the regulations contained in the article 95 paragraph 4 of Law No. 13 of 2003 concerning Labour which prioritizes rights workers for companies declared bankrupt than other creditor rights are in conflict with the norms stated in article 138 of Law No. 37 of 2004 concerning Bankruptcy and the postponement of obligations for debt payments (PKPU Law) that take precedence payments from other separatist credentials rather than workers. 


\section{Result and Discussion}

The objective of the Indonesian State as stated in the fourth paragraph of the Preamble of the Indonesian Constitution 1945 is "to protect the entire Indonesian nation and all of Indonesia's bloodshed and to promote public welfare, educate the nation's life and participate in carrying out world order based on independence, eternal peace and justice social "efforts to realize the goals of the country pursued through national development. Sjachran Basah said that multi-complex development has the effect that the State must intervene in people's lives deeply in all sectors. The intervention is contained in the statutory provisions, both in the Law and in other implementing regulations.

The position of workers/laborers is very important as one element in achieving development goals. Based on this, the employment law has the purpose of protecting the rights and interests of workers/laborers which are normatively regulated in the Constitution and Law Number 13 of 2003 concerning employment. However, with the issuance of the Law on Delaying Debt Payment Obligations, it regulates a different matter where if the company is declared bankrupt, the priority is the separatist creditor, that is, the state as the tax holder and other credentials. This is certainly very much in line with the function of the State which should protect the people and guarantee citizens to get wages from every job. Wages are part of human rights that must be protected by the state.

Human Rights (HAM) is one of the first and foremost words spoken and made an excuse by all humans to support freedom from all oppression. The struggle for upholding the basic rights of citizens has long been echoed since humans used weapons of democracy and human rights to escape from the shackles of colonialism. As the process progressed, the concept of upholding human rights from the 20th century to the present continues to develop. From starting to take away the influence of colonialism to upholding the rights to enjoy a safe legal product, the concept of human rights continues to sprout and as if morphisms becomes a new concept along with the times. But behind these changes, the concept of human rights in both conventional and tangible concepts as a new concept, the concept of human rights remains an inherent, natural concept and remains in every human life, which if the right is abolished naturally also[4].

In general, the Constitution contains the main things such as guarantees for the protection of human rights and citizens, the establishment of fundamental state structures, and the existence of a division of tasks and restrictions on duties, constitutionality which is also fundamental[5].

However, in implementing the regulation, state administrators tend to be ignorant of the provisions stipulated in the constitution so that similar regulations in the field of labor regarding payment of wages to workers are found to be disharmony between similar and equivalent laws. It also has an impact on the practice of enforcing these rules, state administrators, law enforcers, employers tend to ignore the rights of workers who have served the company.

In addition, the Indonesian state adheres to the principle of the rule of law which in this ideology, activities involving people's rights are governed by juridical norms. This state teaching (Staatleer) becomes the basis of anyone who holds statehood to align it with legal norms[6].

Indeed a good or able juridical product is expected to give the best to the community if the manufacturing process is not implemented to neglect the empirical social conditions in the community[7]. 
That principle must be reflected in the practice of state administration, whose juridical construction of each subject or state administration, must limit or constrain power (the principle of rule of law) and not vice versa, because according to experts on the issue of power and corruption, Lord Acton, that power tends to corrupt (power tend to corrupt), the more absolute power, the more absolute the corruption. This is where the role of law (constitution) is needed to control it. From this principle, according to Padmo Wahyono, two thoughts can be expressed, the first is that the highest power (supremacy) in Indonesia is a law made by the people through their representatives in legislative institutions (include understanding the sovereignty of the people). Both the government system or the way the state controls/management requires power in Indonesia there is no power that is not based on law[7].

Therefore, against the disharmony of norms in the Manpower Law regulations with the constitutional Bankruptcy Act, it gives way to every citizen who feels aggrieved by the regulation to conduct a judicial review (testing of the Law to the Constitutional Court as regulated in $24 \mathrm{C}$ of the Republic of Indonesia Constitution NRI) 1945 because the presence of the Constitutional Court as a Guardian Constitution must provide a constitutional interpretation of every application submitted by the community/unity of Adar/or an individual who has a legal standing. Therefore the Constitutional Court has ratified the decision on the judicial review of Law No. 12 In 2003, in its consideration the Court stated that the constitutional wage of workers/laborers pursuant to Article 28 D paragraph (2) of the 1945 Constitution constituted constitutional rights, which therefore constituted the constitutional right to obtain fair and proper treatment in relation to employment. State bills, it is natural to be ranked after wages and rights of workers/laborers (such as severance pay, work period awards, and compensation rights and so on). This is because the State has other sources of funding, while for workers/laborers wages are the only source of survival for themselves and their families. In subsequent consideration, the court stated that the receipt is a part of the things that are reasonable in the management of its business, in addition to the benefits of funds/losses. But for workers/laborers, wages are a means of maintaining the lives of themselves and their families, as guaranteed in article 28 paragraph A of the 1945 Constitution. While in the Constitutional Court decision No. 18/PUU-VI/2008 argues that article 29, article 59 paragraphs 1 , article 138 The 1945 Constitution.

Whereas in an effort to provide better legal guarantees and protection for workers or laborers in the event of bankruptcy, the legislators need to synchronize and harmonize laws relating to the regulation of labor rights.

\section{Conclusion}

From the results of the analysis, it appears that the Constitution guarantees the rights of workers, but in the implementation of the law stipulations relating to employment there is a disharmony of norms, or a request for judicial review from the Constitutional Court is submitted. 


\section{References}

[1] M. Indrasari, "The Effect Of Organizational Culture, Environmental Work, Leadership Style On The Job Satisfaction And Its Impact On The Performance Of Teaching In State Community Academy Bojonegoro," Sinergi J. Ilm. Ilmu Manaj., vol. 7, no. 1, 2017.

[2] A. Suryana, H. Agustin, and M. Hidayat, "Identifying the victims of workplace cyberbullying among lecturers," J. Stud. Komun., vol. 3, no. 2, pp. 151-166, 2019.

[3] M. Syahrul Borman, "Hak Keadilan Untuk Pekerja Outsourcing Paska Putusan Mahkamah Konstitusi," J. Konstitusi, diterbitkan oleh Pus. Kaji. Konstitusi Univ. DR. Soetomo Kerjasama dengan Mahkamah KOnstitusi Republik Indones., vol. Volume 1, no. No 1, p. 17.

[4] Jimly Asshiddiqi, "Hukum Tata Negara dan Pilar-Pilar Demokrasi," Lemb. ilmu Pengetah., 2015.

[5] S. S. Martosoewignyo, "PRESEPSI TERHADAP PROSEDUR DAN SISTEM PERUBAHAN KONSTITUSI DALAM BATANG TUBUH UNDANG-UNDANG DASAR 1945," J. Huk. Pembang., 2017.

[6] Siti Marwiyah, "Pilkada Sebagai Eksaminasi Konstruksi Kedaulatan Rakyat," J. Huk. Kenegaraan, vol. Volume I, no. Nomor I.

[7] Siti Marwiyah, "Peraturan Pemerintah Pengganti Undang-Undang (PERPU) Dalam Hal IkhwalKegentingan Yang Memaksa,” 2015. 